\title{
Analysis of Integrated Report Adoption for Natura Cosmeticos
}

\author{
Jiayang Cheng \\ Accounting Institute, Nanfang College of Sun Yat-sen University, Guangzhou, China \\ Email: chengjiayangacca@sina.com
}

How to cite this paper: Cheng, J. Y. (2021) Analysis of Integrated Report Adoption for Natura Cosmeticos. Open Journal of Business and Management, 9, 489-495. https://doi.org/10.4236/ojbm.2021.92026

Received: December 23, 2020

Accepted: January 20, 2021

Published: January 23, 2021

Copyright (C) 2021 by author(s) and Scientific Research Publishing Inc. This work is licensed under the Creative Commons Attribution International License (CC BY 4.0).

http://creativecommons.org/licenses/by/4.0/

\begin{abstract}
Nowadays, firms pay much more attention to their corporate social responsibilities (CSR) in order to gain good reputations for them and get benefits such as reducing financial constraints from outside parties. Considerations of CSR indicate that these companies do not only focus on improving profits but also take into considerations of non-financial information in their daily operating process. Thus, many firms have shifted their profit-oriented strategies to sustainable development strategies. However, annual reports cannot show the effects of these sustainable strategies' adoption, therefore integrated report, which is long-term oriented and focuses on the impacts of a company's activities on the capitals and on the interrelations generated by such actions, is needed to substitute the original annual report for these firms. This paper mainly conducts research through qualitative methods and literature reviews, aiming at demonstrating the rationalities and effects of integrated report adoption for Natura Cosmeticos based on its current sustainable strategy, which is called "The Triple Bottom Line".
\end{abstract}

\section{Keywords}

Corporate Social Responsibility, Integrated Report, Natura Cosmeticos

\section{Introduction}

Corporate social responsibility (CSR) means while creating profits and assuming legal responsibilities to shareholders and employees, enterprises should also assume responsibilities to consumers, communities and the environment. CSR requires that enterprises must go beyond the traditional idea of taking profit as the only goal, and emphasize the attention to human value in the production process, and emphasize the contribution to the environment, consumers and society (Abuelazm, 2014). This is a new concept of harmony in commercial socie- 
ty. With the development of society, investors gradually recognize and attach importance to CSR. Thus, more and more companies are paying attention to their CSR compliance and choose to disclose their performance in the form of integrated reports. This paper takes Natura Cosmeticos, which is a leading company in Brazilian cosmetics, fragrance \& toiletries market as an example to make analysis of its integrated report adoption. More specifically, it will first identify the sustainable strategy of Natura Cosmeticos and illustrate how it integrates CSR into its strategy. Then this paper will explain what integrated report is and why integrated report is suitable for Natura Cosmeticos to adopt as a substitute for annual report to disclose its CSR compliance. Finally, effects after adopting integrated report for Natura Cosmeticos will also be demonstrated.

\section{Sustainable Strategy of Natura Cosmeticos}

Natura Cosmeticos was founded by Antonio Seabra in 1969 and went public in 2004. Its main markets are Latin America and France. This company had 1.2 million direct sales consultants in 2009 and occupied $23.6 \%$ market shares in 2010. In addition, Natura Cosmeticos also had 55\% household penetration rate and nearly $100 \%$ brand recognition level (Abuelazm, 2014). As a successful company, Natura Cosmeticos always had a characteristic perspective on its organizational goal. It did not only focus on improving firm's profits, but also considered enhancing relationships with shareholders, employees and customers. Current sustainable strategy of Natura Cosmeticos is "The Triple Bottom Line", this strategy concentrates on progress on financial, social, and environmental performance (Eccles, Serafeim, \& Heffernan, 2013). Following are the analysis of how these three aspects are achieved and the results of "the triple bottom line" adoption.

\subsection{Financial}

Natura Cosmeticos promoted its financial performance mainly through its good reputation and unique sales model (Eccles, Serafeim, \& Heffernan, 2013). Firstly, Natura Cosmeticos was the pioneer who took consideration of CSR concept and was famous for its awareness of environmental protection. Thus, the good reputation facilitated Natura Cosmeticos successfully entering the European market and expanding business. Secondly, Natura Cosmeticos adopted direct sales model to boom its sales. Through the brand recognition and revenue yield methods, this company gained more profits than other similar organizations.

\subsection{Social}

Natura Cosmeticos frequently communicated with its stakeholders about responsibilities to society and also discussed investments with stakeholders. Communication is significant within a firm because it can bring various ideas and innovations. To enhance communication, Natura Cosmeticos established a platform named "Stakeholder Engagement Panels and Roundtable Discussion" and a vir- 
tual network called "Natura Conecta", where stakeholders could discuss crucial issues with specialists (Natura Cosméticos S.A., 2015).

\subsection{Environmental}

Natura Cosmeticos preserved environment mainly by using two products: organic alcohol and refill packaging (Natura Cosméticos S.A., 2015). Initially, Natura chose organic alcohol to reduce the greenhouse gas emission, water usage and protected endangered species. This strategy made the company standing out from its competitors who merely focused on economic profitability. Moreover, the refill packing that Natura utilized is made of renewable source of energy, which can help to reduce about $33 \%$ of greenhouse gas emission.

\subsection{Results for Adoption of Sustainable Strategy}

After adopting "the triple bottom line" strategy, Natura Cosmeticos gained huge success in the following aspects (Table 1). Firstly, it had better financial performance than before, net revenue and EBITDA had significant growth rate: net revenue increased from $\mathrm{R} \$ 3.6$ billion in 2008 to $\mathrm{R} \$ 7.0$ billion in 2013, and EBITDA increased from R\$860.1 million in 2008 to $\mathrm{R} \$ 1609.0$ million in 2013. Meanwhile, Natura Cosmeticos was more relevant in the international market and $14 \%$ of the net revenue came from international market in 2013 compared with $6 \%$ in 2008 . These good financial performances resulted in a dividend distribution of $100 \%$ net income (total amount was $\mathrm{R} \$ 861$ million) in 2013. Secondly, Natura Cosmeticos made more contributions to the whole society. It provided more jobs to people (numbers of consultants increased from $850 \mathrm{k}$ in 2008 to $1.6 \mathrm{MM}$ in 2013) and created more wealth for the whole society (investment increased from $\mathrm{R} \$ 103$ million in 2008 to $\mathrm{R} \$ 554$ million in 2013; wealth creation for number of households increased from 1895 in 2008 to 3571 in 2013). In addition, Natura invested more in educational projects in 2013 (R $\$ 17.1$ million) than that in 2008 (R $\$ 3.7$ million). Thirdly, Natura Cosmeticos also did very well in environmental protection aspect. It spent significant investments in R\&D than ever before ( $\mathrm{R} \$ 100$ million in 2008 and $\mathrm{R} \$ 183$ million in 2013) and made outstanding achievements in reducing carbon dioxide $\left(\mathrm{CO}_{2}\right.$ emission decreased from $3.8 \mathrm{~kg}$ in 2008 to $2.8 \mathrm{~kg}$ in 2013 for product invoiced).

Table 1. Solid track-record of triple bottom line results.

\begin{tabular}{ccc}
\hline $\begin{array}{c}\text { Growth of network } \\
\text { (number of consultants) } \\
\text { Strong net revenue growth } \\
(\mathrm{R} \$ \text { billions) } \\
\begin{array}{c}\text { More relevant in the international market } \\
(\% \text { of net revenue) }\end{array}\end{array}$ & from 2008 & to 2013 \\
\hline
\end{tabular}




\begin{tabular}{|c|c|c|}
\hline $\begin{array}{l}\text { Strong EBITDA growth } \\
\text { (R\$ million) }\end{array}$ & $\mathrm{R} \$ 860.1$ & $\mathrm{R} \$ 1609.0$ \\
\hline $\begin{array}{l}\text { Significant investments in R\&D } \\
\text { (R\$ million) }\end{array}$ & $\mathrm{R} \$ 100$ & $\mathrm{R} \$ 183$ \\
\hline $\begin{array}{l}\text { New level of investment } \\
\quad(\mathrm{R} \$ \text { million Capex })\end{array}$ & $\mathrm{R} \$ 103$ & $\mathrm{R} \$ 554$ \\
\hline $\begin{array}{c}\text { Strong dividend payout } \\
\text { (R\$ million and \% net income) }\end{array}$ & $\begin{array}{c}\mathrm{R} \$ 499 \\
(95.4 \%)\end{array}$ & $\begin{array}{l}\mathrm{R} \$ 861 \\
(100 \%)\end{array}$ \\
\hline $\begin{array}{l}\text { Reduction in } \mathrm{CO}_{2} \text { emissions } \\
\left(\mathrm{CO}_{2} \mathrm{e} / \mathrm{kg} \text { product invoiced }\right)\end{array}$ & $3.8 \mathrm{~kg}$ & $2.8 \mathrm{~kg}$ \\
\hline $\begin{array}{l}\text { Wealth creation for supplier communities } \\
\text { (number of households) }\end{array}$ & 1895 & 3571 \\
\hline $\begin{array}{l}\text { Investment in educational projects through crer para ver line } \\
\qquad(\mathrm{R} \$ \text { million) }\end{array}$ & $\mathrm{R} \$ 3.7$ & $\mathrm{R} \$ 17.1$ \\
\hline
\end{tabular}

\section{Integrated Report}

\subsection{What Is an Integrated Report}

An integrated report (IR) is a concise communication about how an organization's strategy, governance, performance and prospects, in the context of its external environment, lead to the creation of value in the short term, medium and long term. It is a blended materiality of financial report and sustainability report. IR is a new approach of corporate report, which is rapidly gaining international recognition. It is founded on integrated thinking, which helps demonstrate interconnectivity of strategy, strategic objectives, performance, risk and incentives and helps to identify sources of value creation. IR aims at building strong relationships with stakeholders, building a loyal customer base, developing intellectual capital and managing environmental risks. It tends to fall off the radar when corporate execs think short term (Adam, 2014).

\subsection{Differences between Annual Report and Integrated Report}

Fasan (2013) states that an annual report (AR) is a comprehensive report on a company's activities throughout the preceding year. AR is intended to give shareholders and other interested people information about the company's activities and financial performance. IR is an evolution of $A R$, the most difference between IR and AR is that IR is long-term oriented and focuses on the impacts of a company's activities on the capitals and on the interrelations generated by such actions (Adam, 2014).

\subsection{Pros and Cons of Integrated Report}

There are many advantages of adopting IR. It has a positive impact on external engagement with stakeholders, including investors. In addition, IR let investors better understand their strategies and make managers better understand the 
firm's risks and opportunities so that help managers make improvements in decision making. As for disadvantages of adopting IR, it should not be denied that IR is very complex and lack of clarity. There is a lack of consensus in terms of what exactly IR will look like. And lack of accepted standards is also a related problem (Wetch, 2013).

\section{Why Integrated Report Is Suitable for Natura Cosmeticos to Adopt}

Natura Cosmeticos has many characteristics that predispose it to adopt integrated report. These characteristics can be classified into two types: internal characteristics and external characteristics.

\subsection{Internal Characteristics}

One of the internal characteristics is the firm's strategy. At the beginning of 1990s, Natura Cosmeticos' strategy evolved into one, which focused on corporate social and environmental responsibility and sustainable development. The firm took several actions in order to reflect their devotion into maintain a good relationship with society and environment. For example, the firm used organic alcohol and refill packing in order to reduce pollutions to environment. The firm also kept close relationships with its stakeholders in order to build a good brand image. Another internal characteristic is leadership. Since the firm found, Natura Cosmeticos' managers believed the company was part of a larger system that required balance in order to prosper. Therefore, considering above two internal characteristics, IR is more suitable for Natura Cosmetics to adopt than AR because IR can show the firm's efforts in sustainable development and attract more customers by its CSR compliance performance.

\subsection{External Characteristics}

Natura Cosmeticos attaches great importance to the requirements of stakeholders. On the one hand, customers are becoming more concerned about the non-financial performance of the company. The communities are also concerned the effects made by the firm on the environment. It is necessary for $\mathrm{Na}$ tura to make integrated report in order to public what the firm has done in social and environmental aspects. On the other hand, in such a highly competitive market (cosmetic market), Natura Cosmeticos needs to distinguish itself from other competitors. Providing integrated report is beneficial for Natura Cosmeticos to build a responsible brand image, which can attract more customers. In addition, it is also a trend that the non-financial information disclosure plays a more important role in the market.

\section{Effects after Natura Cosmeticos Adopted Integrated Report}

As a pioneer in integrated reporting practice, Natura Cosmeticos published its 
sustainability and financial reports in a single document encompassing all dimensions of the business: financial, social and environmental in 2002. It did not only be involved in the main global forums discussing integrated reporting, but also participated in the International Integrated Reporting Council (IIRC) seeking to create a global standard for integrated reports (Integrated Reporting, 2016). Following are the effects after Natura Cosmeticos adopted integrated report. Firstly, Adoption of IR changed this firm's behaviors. IR showed both financial and non-financial information, thus in order to present good performance in CSR compliance, Natura Cosmeticos had to make a lot of efforts in other aspects other than maximizing profits. For example, after adopting IR, it spent more money than ever before in $\mathrm{R} \& \mathrm{D}$ in order to develop environmental-friendly products with lower pollute emissions. After years' significant investment, finally it made outstanding achievements in protecting environment $\left(\mathrm{CO}_{2}\right.$ emission decreased from $3.8 \mathrm{~kg}$ to $2.8 \mathrm{~kg}$ for product invoiced). Secondly, adoption of IR resulted in better business decisions for Natura Cosmeticos. During the early years of adopting integrated report (2000-2006), Natura Cosmeticos tried to form an integrated management culture environment. An integrated management culture asked employees to think about impacts of their decisions in three dimensions (financial, social and environmental) (Abuelazm, 2016). By using this way, sense of responsibility towards business surroundings shall be reinforced and business decision maker shall look at decisions in a more holistic approach in the light of the reported information. Thus, it can be seen that integrated report adoption can ultimately change enterprise's behaviors and ensure better, more effective long-term decisions can be made (Natura Cosméticos S.A., 2014).

\section{Conclusion}

In general, as a leading company in Brazilian cosmetics, fragrance \& toiletries market, Natura Cosmeticos always had a characteristic perspective on its organizational goal. It adopted a new strategy focusing on corporate social and environmental responsibility and sustainable development, which aimed at making progress on financial, social and environmental aspects. Based on Natura Cosmeticos' new sustainable strategy, as well as outside stakeholders' expectations, it is more suitable for this firm to adopt IR to substitute original AR to make disclosure because IR adoption can show the firm's efforts in sustainable development and its CSR compliance performance, so as to build a responsible brand image and attract more customers. As for effects, adoption of IR changed this firm's behaviors and also resulted in better business decisions, which enhanced Natura Cosmeticos' reputations and strengthened its brand loyalties. Last but not least, this paper has deficiencies in the following aspects: first of all, this paper focuses on the time period of 2008-2013 and does not track Natura Cosmeticos' CSR performance and integrated report disclosure after the year 2013. Besides, this article only discusses about the rationalities of Natura Cosmeticos' IR 
adoption, but there is no discussion for the quality of IR disclosure, thus future studies can make in-depth research in the above aspects.

\section{Conflicts of Interest}

The author declares no conflicts of interest regarding the publication of this paper.

\section{References}

Abuelazm (2014). A Case about Natura Cosmeticos of Brazil and How They Adapted Integrated Reporting. Business, Technology.

Abuelazm (2016). Natura Cosmeticos S.A.-An Integrated Reporting Case. Slideshare.

Adam, C. (2014). What Is Integrated Reporting? And How Do You Do It? Towards Sustainable Business.

Eccles, R.G., Serafeim, G., \& Heffernan, J. (2013). Natura Cosmeticos, S.A.SSRN.

Fasan, M. (2013). Annual Reports, Sustainability Reports and Integrated Reports: Trends in Corporate Disclosure. In C. Busco et al. (Eds.), Integrated Reporting (pp. 41-57). Cham: Springer. https://doi.org/10.1007/978-3-319-02168-3_3

Integrated Reporting (2016). Towards Integrated Reporting-Communicating Value in the 21st Century. IIRC.

Natura Cosméticos S.A. (2014). GRI Indication Section Report, Brazil.

Natura Cosméticos S.A. (2015). Annual Report 2015, Brazil.

Wetch, I. (2013). The Benefits and Downsides of Integrated Reporting. The Accountant. 